\title{
PERANCANGAN DAN IMPLEMENTASI SISTEM \\ ORTHOGONAL FREQUENCY DIVISION MULTIPLEXING (OFDM) DENGAN MENGGUNAKAN DSK-TMS320C6713
}

\section{DESIGN AND IMPLEMENTATION ORTHOGONAL FREQUENCY DIVISION MULTIPLEXING (OFDM) SYSTEM BY USING DSK-TMS320C6713}

\author{
${ }^{1}$ Dwi Aryanta, ${ }^{2}$ Arsyad Ramadhan Darlis, ${ }^{3}$ Yusup Mulyadi \\ 1, 2,3 Jurusan Teknik Elektro Institut Teknologi Nasional (ITENAS) Bandung \\ $\underline{1 \text { dwiaryanta@gmail.com }}, \underline{{ }^{2} \text { arsyaddarlis@gmail.com, }}$, yusup.mulyadi16@gmail.com
}

\begin{abstract}
Abstrak
OFDM adalah salah satu teknik transmisi yang menggunakan beberapa buah frequency subcarrier yang saling tegak lurus (orthogonal). Karakteristik yang saling tegak lurus membuat frequency subcarrier dapat saling overlap tanpa menimbulkan interferensi. Dilakukan perancangan sistem OFDM dengan menggunakan DSK (Digital Signal Processing Starter Kit) TMS320C6713 berbasis m-file dan Simulink dengan menggunakan beberapa modulasi diantaranya QPSK, 16QAM, dan 64QAM. Pengujian dilakukan dengan membandingkan hasil keluaran dari diagram konstelasi sinyal, sinyal OFDM, dan Bit Error Rate (BER) pada m-file, Simulink dan DSK TMS320C6713. Hasil BER yang ditunjukan pada saat implementasi, Modulasi QPSK memiliki nilai BER yang paling baik dari pada modulasi 16QAM dan 64QAM. Pada nilai Eb/No 10dB, modulasi QPSK memiliki nilai BER sebesar 0,14400, modulasi 16-QAM memiliki nilai BER sebesar 0,253600, dan modulasi 64-QAM memiliki nilai BER sebesar 0,288700. Kemudian modulasi QPSK memiliki efisiensi memori yang paling baik sebesar 1,0530303\% setelah diimplementasikan pada DSK TMS320C6713.
\end{abstract}

\section{Kata Kunci : OFDM,Modulasi, Diagram Konstelasi, BER, DSK TMS320C6713}

\begin{abstract}
OFDM is a transmission technique that uses multiple pieces of frequency subcarrier which is orthogonal. The orthogonal caracteristic make frecuency subcarrier can be overlap without causing interference. OFDM system was design with DSK (Digital Signal Processing Starter Kit) TMS320C6713 that based m-file and simulink using several modulation including QPSK, 16QAM, dan 64QAM. The evaluation was done by comparing the ouput from constellation signal diagram, OFDM signal and BER (Bet Error Rate) on m file, Simulink and DSK TMS320C6713. The BER result when implementation showedthat QPSK modulation has a better BER value than 16-QAM and 64-QAM modulation. The value on Eb/No 10dB, QPSK modulation has BER value 0,14400, 16-QAM has BER value 0,253600, and 64-QAM has BER value 0,288700. Then QPSK modulation has the most excellent memory efficiency of $1.0530303 \%$ after implemented on the TMS320C6713 DSK
\end{abstract}

Keywords : OFDM, Modulation, constellation diagram, BER, DSK TMS320C6713 


\section{PENDAHULUAN}

OFDM merupakan salah satu teknik transmisi yang memungkinkan spektrum sinyalnya dipisahkan ke dalam beberapa frequency subcarrier yang saling tegak lurus (orthogonal). OFDM juga merupakan salah satu teknologi dalam bidang telekomunikasi yang memungkinkan penggunaan bandwidth lebih efektif. Keunggulan tersebut yang membedakan teknik transmisi frequency multicarrier OFDM dengan teknik transmisi frequency multicarrier yang lain.

Dalam penelitian yang ditulis oleh Pontas Poncius Situmorang dari program studi teknik elektro universitas indonesia dengan judul Rancang bangun rangkaian penerima OFDM dengan menggunakan DSP Starter Kit (DSK) TMS320C6713 berbasis simulink [7] dijelaskan mengenai sistem penerima OFDM dengan menggunakan simulink. Selanjutnya penulis mentransfer skema yang telah berhasil dibuat tadi kedalam perangkat DSK TMS dan menggunakan osciloscope untuk melihat sinyal keluaran dari kit DSK.

Kemudian pada penelitian yang ditulis oleh Novan Ferdian Djafar dari program studi teknik elektro universitas Indonesia pada tahun 2009 dengan judul Rancang bangun rangkaian pengirim ODFM dengan Huffman code pada DSK TMS320C6713 menggunakan Simulink [3] dijelaskan mengenai rangkaian pengirim pada OFDM. Perbedaan dengan penelitian sebelumnya adalah terdapatnya Huffman code pada awal proses pengiriman sinyal informasi

Penelitian memiliki tujuan yaitu merancang dan mengimplementasikan teknik transmisi OFDM dengan menggunakan modulasi digital pada DSK TMS 320C6713 . Adapun agar lebih terarah dan jelas penulis membatasi kajian yang akan dibahas yaitu modulasi yang digunakan yaitu modulasi QPSK, 16QAM, 64QAM, dengan kanal AWGN, dan tidak menggunakan teknik perbaikan kualitas sinyal.

\section{DASAR TEORI DAN PERANCANGAN}

\subsection{Orthogonal Frequency Division Multiplexing (OFDM)}

Sifat orthogonal dalam Orthogonal Frequency Division Multiplexing (OFDM) mengandung makna hubungan matematis antara frekuensi - frekuensi yang digunakan. Dengan persamaan matematika bisa diekspresikan sebagai berikut:

$$
\begin{array}{lll}
\int_{a}^{b} \psi_{p}(t) \psi_{q}^{*}(t) d t=0 & \text { dan } & \int_{a}^{b} \psi_{p}(t) \psi_{q}^{*}(t) d t=\mathrm{K} \\
\text { untuk } \mathrm{p} \neq \mathrm{q} & \text { untuk p=q }
\end{array}
$$

\subsubsection{Fast Fourier Transform (FFT) dan Inverse Fast Fourier Transform (IFFT)}

Pada sistem OFDM, hubungan antara subcarrier-subcarrier orthogonal dapat diimplementasikan dengan menggunakan transformasi Fourier, dimana pada sisi pemancar OFDM (modulator) menggunakan Inverse Fast Fourier Transform (IFFT) dan Fast Fourier Transform (FFT). Untuk persamaan FFT dan IFFT dapat dituliskan sebagai berikut.

1) FFT:

$$
x(k)=\sum_{n=0}^{N-1} x(n) \sin \left(\frac{2 \pi k n}{N}\right)+j \sum_{n=0}^{N-1} x(n) \cos \left(\frac{2 \pi k n}{N}\right)
$$

2) IFFT:

$$
x(n)=\sum_{n=0}^{N-1} x(k) \sin \left(\frac{2 \pi k n}{N}\right)-j \sum_{n=0}^{N-1} x(k) \cos \left(\frac{2 \pi k n}{N}\right)
$$




\subsubsection{Cyclic Prefix}

Cyclic Prefix adalah mekanisme penambahan simbol dengan cara mengambil beberapa simbol di akhir frame IFFT untuk dimasukkan pada awal frame.

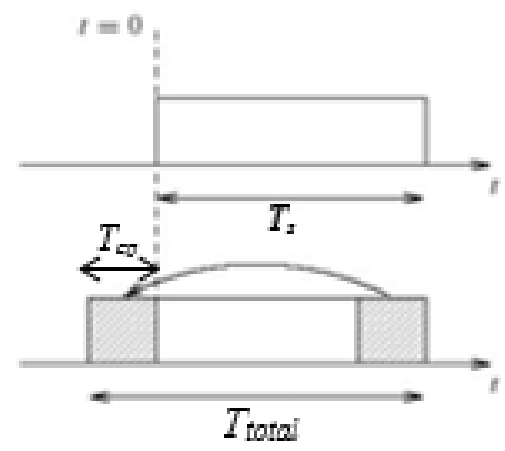

Gambar 1. Pola Dari Cyclic Prefix

Pada Gambar 1 diatas menunjukkan pola dari cyclic prefix dimana bagian belakang frame dengan panjang tertentu diduplikasikan dan diletakkan ke depan pada awal frame data tersebut, sehingga laju simbol $\mathrm{T}_{\text {total }}$ akan lebih panjang. Dari gambar diatas dapat dibuat suatu persamaan tentang panjang keseluruhan dari simbol OFDM yaitu:

$$
\text { Ttotal }=T c p+T s
$$

\subsection{DSK TMS320C6713}

Digital Signal Processing (DSP) processor, seperti keluarga processor TMS320C6x adalah mikroprocessor berkecepatan tinggi dengan tipe arsitektur dan set instruksi khusus untuk pemrosesan sinyal. Sistem dasar DSP processor terdiri dari analog-to-digital converter (ADC) untuk menangkap sinyal masukan analog. Hasil representasi digital dari sinyal kemudian diproses oleh DSP processor, misal C6x, kemudian hasil keluarannya diubah kembali menjadi sinyal analog melalui digital-to-analog converter (DAC).

\subsection{Perancangan Sistem OFDM}

Rancangan penelitian yang disusun oleh penulis awalnya dari membuat source code pada matlab dengan $m$-file yang nantinya menjadi acuan oleh penulis untuk melanjutkan pemodelan ketahap selanjutnya yaitu dengan Matlab simulink. Adapun parameter parameter yang akan dibuat pada sistem OFDM ini ditunjukan pada Tabel 1 dan tahapan untuk perancangan system dapat dilihat pada flowchart Gambar 2.

Tabel 1 Parameter Sistem OFDM

\begin{tabular}{|l|l|}
\hline Jumlah Subcarrier & 192 \\
\hline Jumlah Pilot Simbol & 8 \\
\hline IFFT Size & 256 \\
\hline Teknik Modulasi & QPSK, 16QAM, 64QAM \\
\hline Variasi Eb/No & $0-50 \mathrm{~dB}$ \\
\hline
\end{tabular}




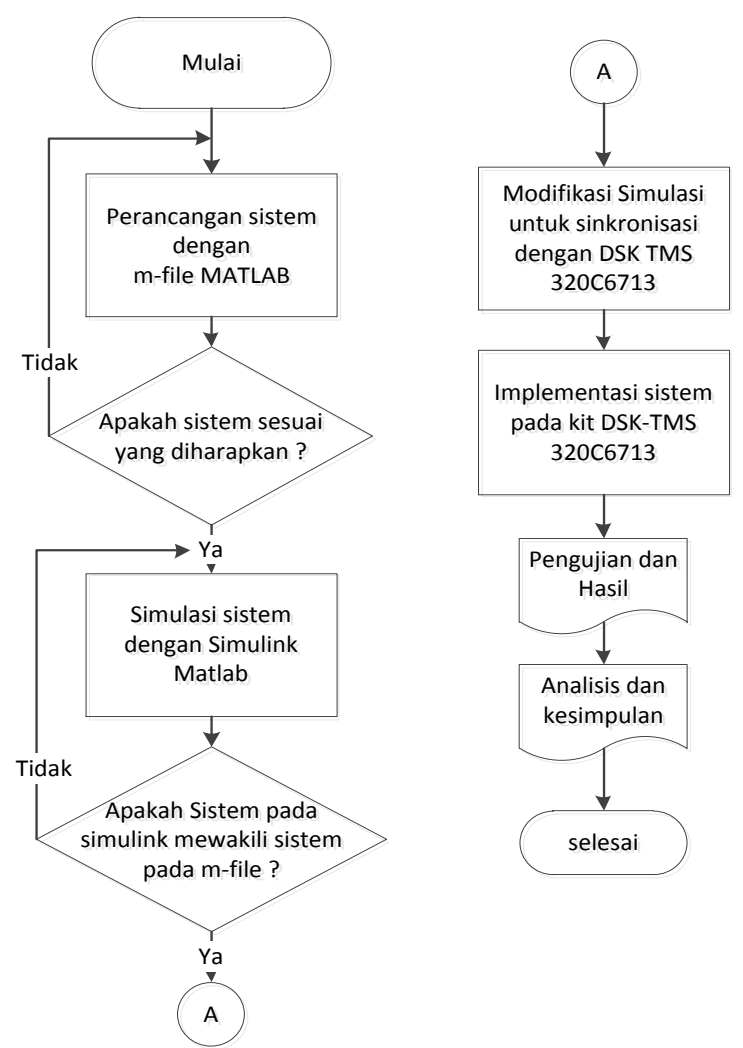

Gambar 2 . Flowchart Perancangan Sistem Transmisi OFDM

\subsection{Simulasi Sistem OFDM}

Simulasi sistem OFDM yang dirancang yaitu dengan menggunakan Matlab m-file dan Matlab simulink. Dari kedua model yang akan dibangun dengan menggunakan langkah alur sistem yang sama. Adapun pemodelannya dapat dilihat pada Gambar 3.

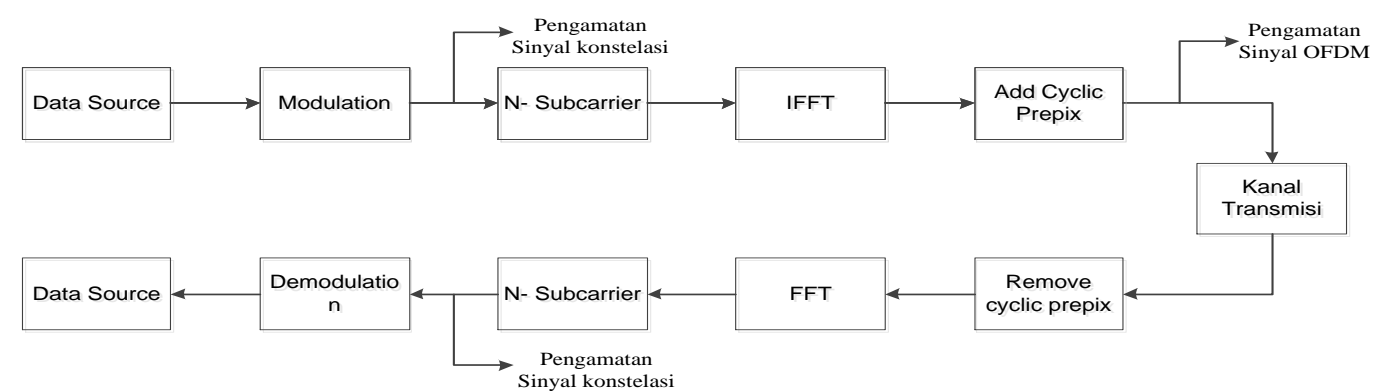

Gambar 3. Simulasi Sistem OFDM

\subsubsection{Simulasi dengan mfile}

Source code yang ada pada $m$-file ini akan menjadi dasar bagi penulis dalam menginputkan parameter parameter yang nantinya dibutuhkan dalam simulasi simulink. Bagian yang akan diuji pada perancangan $m$-file antara lain diagram konstelasi, Symbol OFDM, Data Rate sistem secara Teori, dan Bit Error Rate (BER).

\subsubsection{Simulasi menggunakan simulink}

Pada tahap ini simulasi sistem dilakukan dengan membuat tiap blok sistem berdasarkan rancangan dari code $m$-file yang sebelumnya telah dibuat menggunakan Matlab Simulink. Ada beberapa tahapan pembuatan blok, yaitu Pembangkit Sinyal Informasi, OFDM Transmitter (Tx), 
Kanal AWGN, OFDM Receiver (Rx), Signal Conditioning, dan output BER. Gambar 4 merupakan blok-blok bagian yang diperlukan pada simulasi simulink.

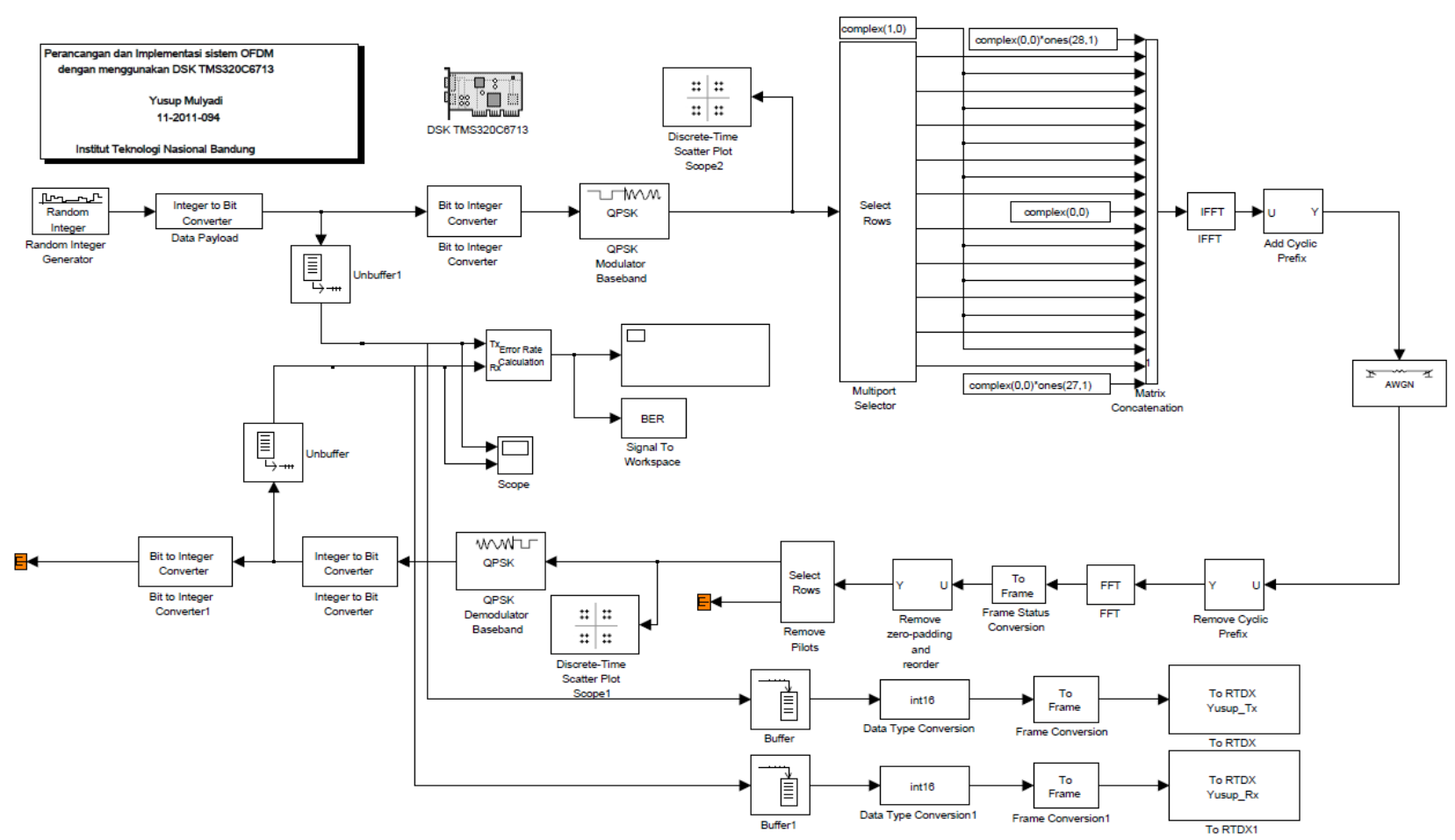

Gambar 4 . Blok Simulasi sistem OFDM

\section{PEMBAHASAN}

Sistem yang akan dilakukan pengujian menggunakan 3 jenis modulasi, yaitu modulasi QPSK, 16-QAM, dan 64-QAM. Dalam pengujian sistem ini akan dilakukan pengamatan pada bagian Diagram konstelasi, Sinyal OFDM, dan Bit Error Rate (BER) yang keluar dari sistem.

\subsection{Diagram Konstelasi}

Pengamatan sinyal konstelasi dilakukan pada sisi pengirim di bagian setelah modulator dan pada sisi penerima dibagian sebelum demodulator. Pengamatan ini dilakukan pada perancangan $\mathrm{m}$ file dan simulasi Simulink. Gambar 5 merupakan hasil dari diagram konstelasi penerima pada nilai $\mathrm{Eb} / \mathrm{No}$ 30dB.

Dari hasil diagram konstelasi yang telah melewati kanal AWGN, dapat dianalisis bahwa setiap diagram konstelasi menjadi terdistribusi menyimpang dan tidak beraturan pada semua jenis modulasi, hal ini karena karakteristik dari kanal AWGN yang terdapat noise. Sehingga menyebabkan sinyal yang dikirim, tidak sama dengan sinyal yang diterima jika tidak mencapai level Eb/No minimum yang dibutuhkan pada masing masing modulasi.

Nilai amplitude dan phase pada bagian pengirim dan penerima sinyal sudah sesuai dengan mapping yang diharapkan jika memiliki nilai Eb/No 20dB untuk modulasi QPSK, 30dB untuk modulasi 16-QAM dan 40dB modulasi 64-QAM. Pengaruh peningkatan Eb/No yang semakin besar ini karena jumlah bit/symbol yang lebih tinggi memerlukan energi pengiriman yang lebih tinggi untuk mencapai mapping yang diharapkan. 


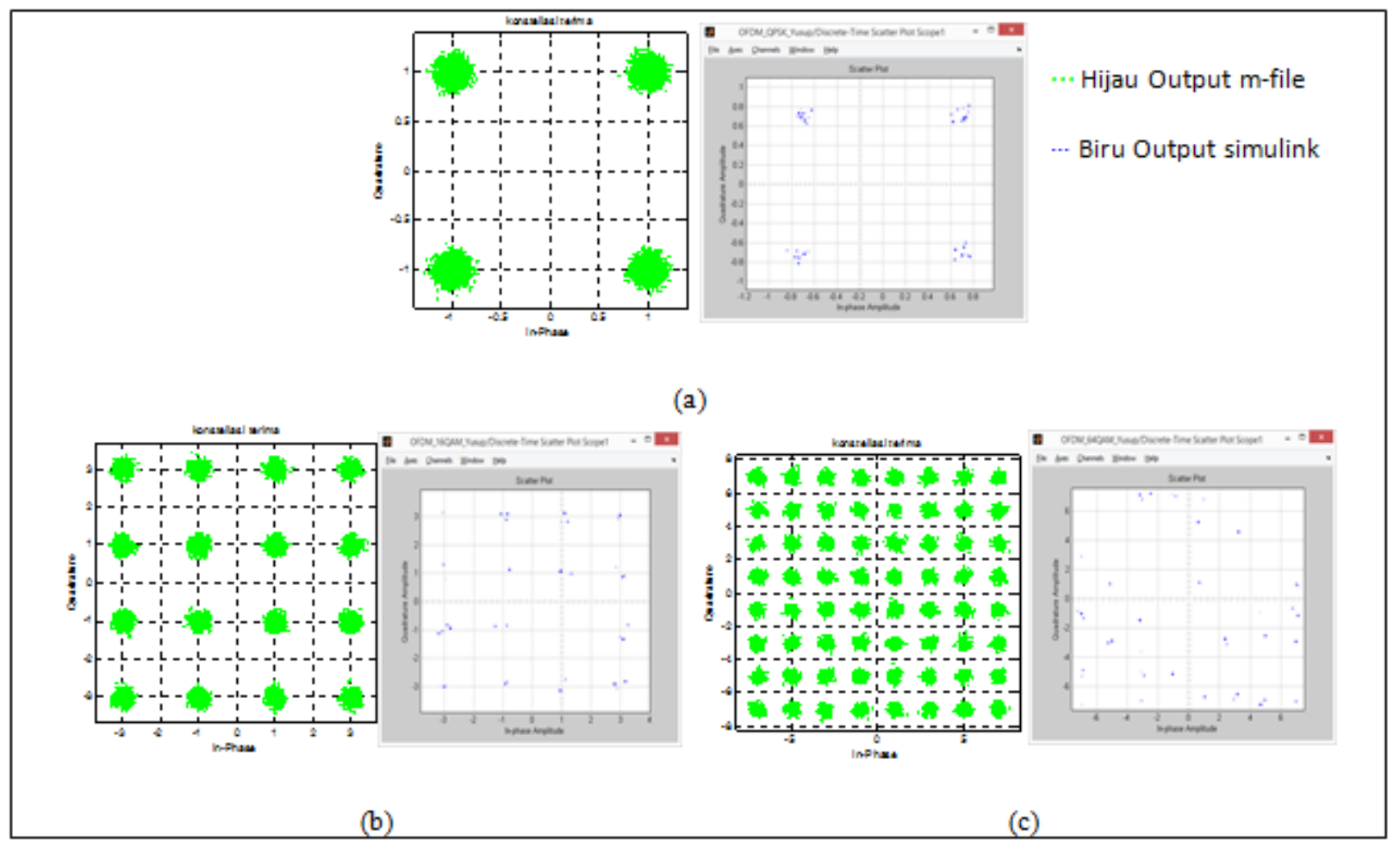

Gambar 5. Diagram sinyal konstelasi pada sisi penerima 30dB, (a) Modulasi QPSK, (b) Modulasi 16-QAM, (c) Modulasi 64-QAM

\subsection{Sinyal OFDM}

Bagian yang akan diamati pada proses pengujian kali ini yaitu sinyal OFDM keluaran dari sistem. Pengamatan pertama dilakukan pada saat sistem dijalankan pada simulink, dan yang kedua adalah pada saat sistem berada pada DSK TMS320C6713.

\subsubsection{Sinyal OFDM pada Simulink}

Pada bagian ini akan dilihat sinyal OFDM hasil keluaran dari sistem yang dijalankan pada simulink. Sinyal OFDM yang dihasilkan oleh sistem sebelum melewati kanal AWGN dapat dilihat pada Gambar 6

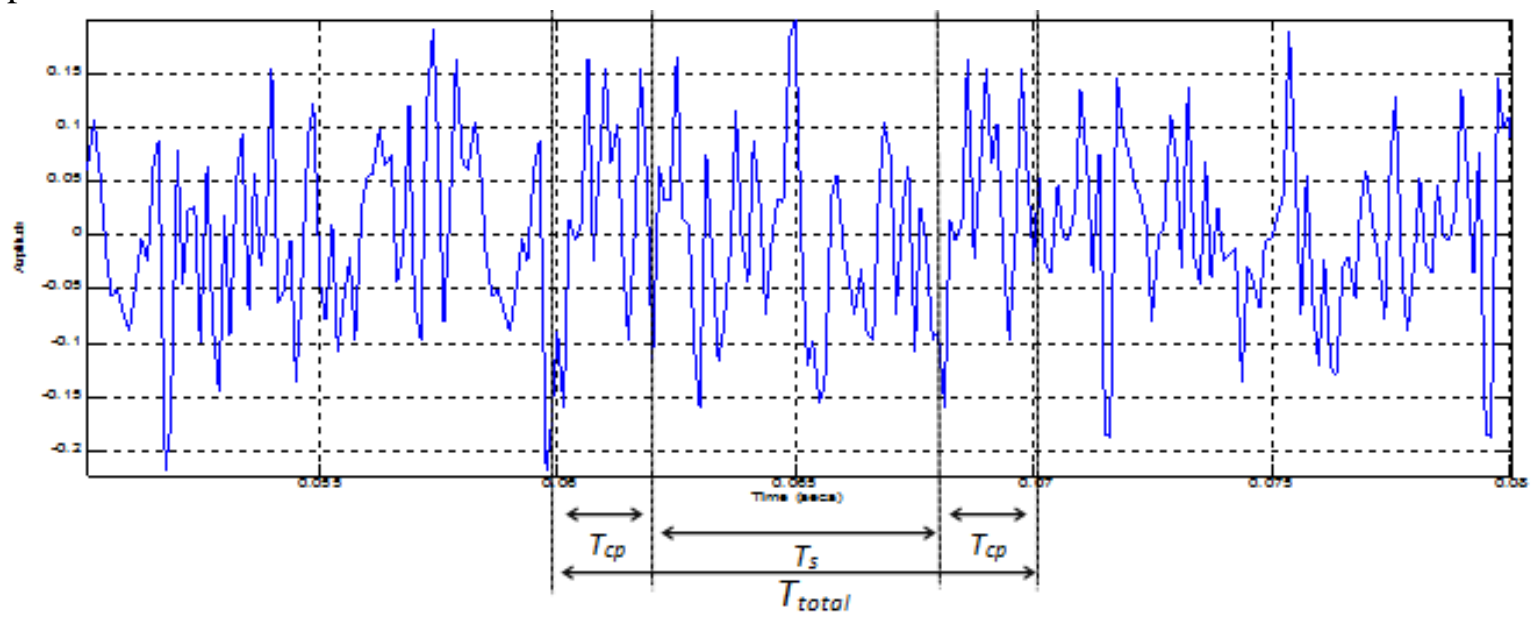

Gambar 6. Simbol OFDM simulink 
Gambar 6 merupakan sinyal OFDM keluaran dari simulink, pada gambar tersebut terlihat bahwa perioda simbol OFDM yaitu Ttotal $=0,01 \mathrm{~s}$, dimana pada bagian itu terdiri dari $\mathrm{Ts}=0,006 \mathrm{~s}$ dan $\mathrm{Tcp}=0,002 \mathrm{~s} \times 2$.

\subsubsection{Sinyal OFDM DSK TMS320C6713}

Sebelum melihat Simbol OFDM pada DSK TMS320C6713, pada sistem dilakukan penambahan blok berupa Digital to Analog Converter (DAC) sebelum melewati kanal AWGN, ini dilakukan untuk melihat simbol OFDM menggunakan osciloscope.

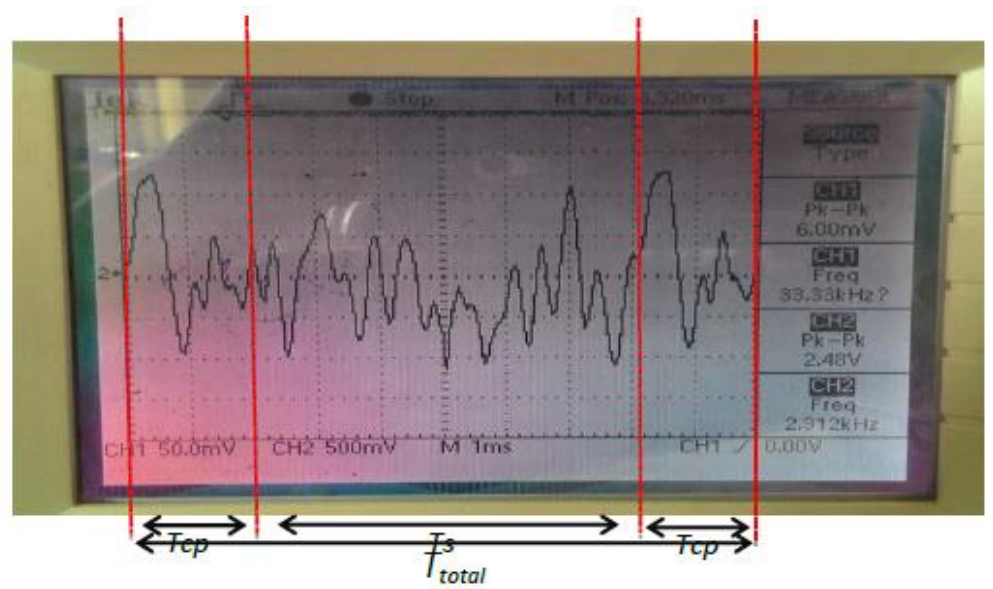

Gambar 7. Simbol OFDM kit DSK TMS-320C6713

Pada Gambar 7, osciloscope menunjukan Time/div sebesar 1ms maka didapatkan nilai $\mathrm{T}_{\text {total }}$ $=0,01 \mathrm{~s}$, dimana dalam $0,01 \mathrm{~s}$ tersebut terdapat $\mathrm{Ts}=0,006 \mathrm{~s}$ dan $\mathrm{Tcp}=0,002 \mathrm{~s} \times 2$. Hasil Sinyal OFDM keluaran simulink dan kit DSK terlihat ada cyclic prefix yang sama di akhir dan awal simbol. Kemudian pada data osciloscope level amplitude sebesar 2,48 p-p sedangkan pada simulink level amplitude sebesar 0,4 p-p. Perbedaan amplitude dikarenakan komponen DAC yang ditambahkan pada proses pengambilan sinyal pada osciloscope, pada blok DAC terdapat pengaturan level minimum sampling rate sebesar $8 \mathrm{KHz}$. Selanjutnya proses perubahan sinyal Digital menjadi Sinyal Analog juga berpengaruh pada besaran tegangan keluaran sistem pada kit DSK

\subsubsection{Perhitungan Bit Rate}

Setelah dilakukan pengamatan pada keluaran simulink dan DSK TMS320C6713, didapat perioda sinyal OFDM $\mathrm{T}_{\text {total }}$ sebesar 0,01 s. Dari data tersebut kita dapat melakukan perhitungan Bit rate yang keluar pada sistem dengan menggunakan persamaan :

$$
\text { Nsubcarrier } \cdot(n) \text { modulation } \cdot \text { coding rate } \cdot(R s)=R b
$$

Nilai durasi simbol atau $R s=1 /$ Ttotal $=100 \mathrm{symbol} / \mathrm{s}$. Dari persamaan (5) dengan jumlah subcarrier sebanyak 192, pada modulasi QPSK didapatkan Bit rate sebesar 38,4 Kb/s , pada modulasi 16-QAM sebesar 76,8 Kb/s, dan pada modulasi 64-QAM sebesar 115,2 Kb/s.

\subsection{Bit Error Rate (BER)}

Pada Bagian ini akan dijelaskan mengenai perubahan BER berdasarkan kenaikan Eb/No terhadap berbagai teknik modulasi. Pengujian dilakukan pada kanal AWGN dengan Eb/No $0 \mathrm{~dB}$ sampai $50 \mathrm{~dB}$ dengan step sebesar 2dB. Jumlah data yang dikirimkan sebanyak 10.000 bit, BER 
yang akan diuji yaitu BER pada tahap perancangan dengan $m$-file, simulasi simulink, dan BER yang keluar pada kit DSK.

\subsubsection{Modulasi QPSK, 16-QAM, dan 64-QAM}

Pada bagian ini akan dilihat BER keluaran sistem dari m-file, simulink, dan implementasi pada DSK TMS320C6713. Nilai BER yang keluar pada sistem dapat dilihat pada Gambar 8.

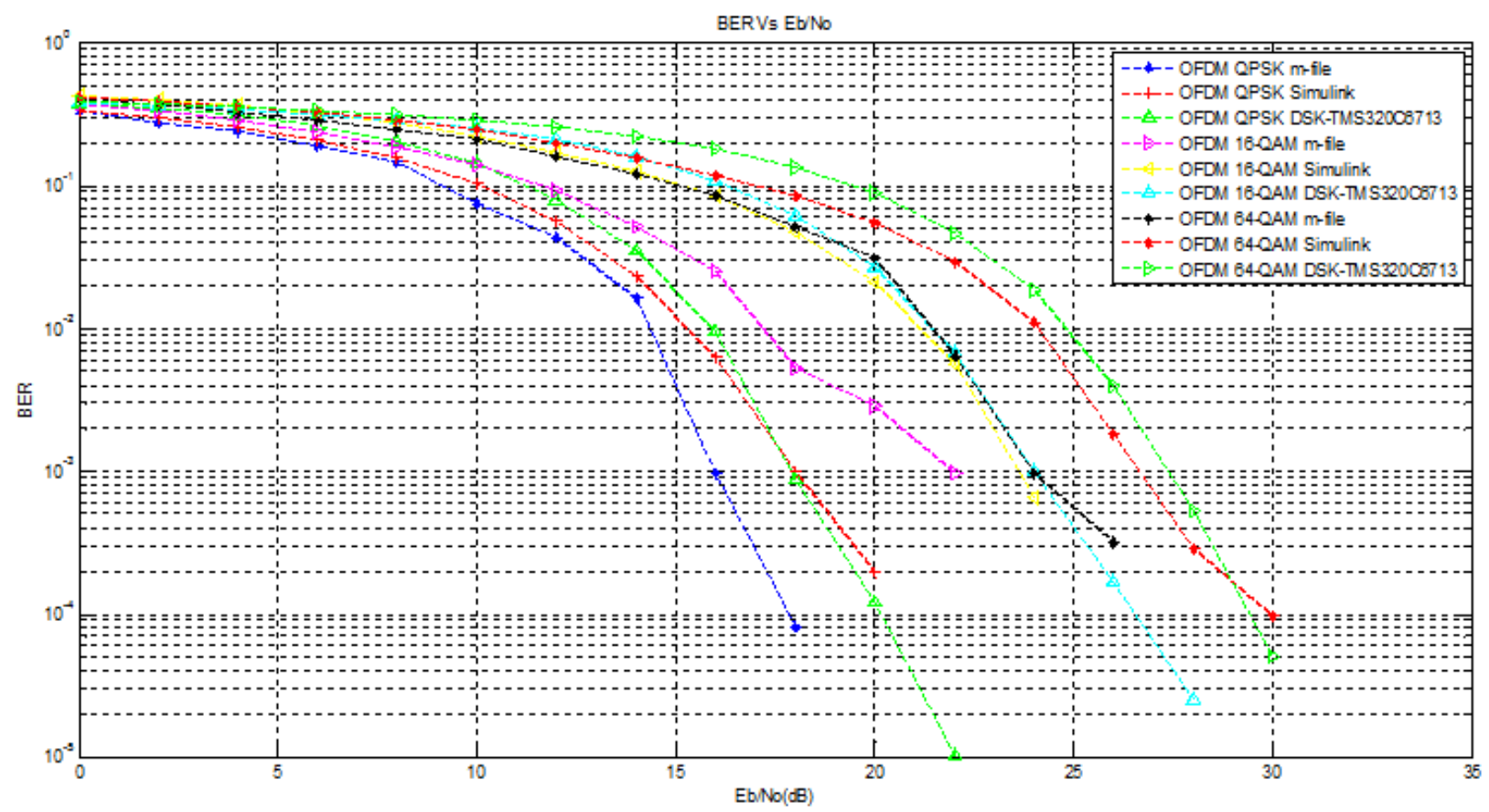

Gambar 8. BER sistem OFDM Modulasi QPSK, 16QAM, dan 64-QAM

Dari grafik Gambar 8 hasil dari nilai BER sistem yang dibuat pada $m$-file, mengalami perbedaan dengan nilai BER hasil keluaran simulink ataupun kit DSK. Hasil keluaran m-file selalu lebih baik dari keluaran simulink dan kluaran kit DSK, sementara kluaran simulink dan kit DSk nilainya selalu berdekatan. Perbedaan ini dimungkinkan karena terjadinya penambahan blok yang diperlukan pada saat pembuatan simulasi simulink seperti rate transtition, buffer yang menyababkan model tidak sama persis dengan hasil BER m-file. Kemudian terdapat noise konektor keluran BER pada kit DSK yang menggunakan USB.

\subsubsection{Perbandingan Hasil Implementasi}

Pada bagian ini akan dilihat perbandingan hasil implementasi pada kit DSK TMS320C6713 dengan berbagai teknik modulasi yaiyu QPSK, 16QAM, dan 64QAM. Hasil perbandingan tersebut dapat dilihat pada Gambar 9.

Dari grafik Gambar 9 dapat dilihat bahwa sistem dengan modulasi QPSK akan lebih baik nilai BER yang dihasilkan dari pada sistem yang menggunakan modulasi 16QAM dan 64QAM. Keadaan kestabilan sistem ini berbeda karena jumlah bit/symbol yang dibutuhkan modulasi QPSK, lebih sedikit dari pada sistem yang menggunakan modulasi 16QAM dan 64QAM. Hasil ini menunjukan bahwa BER keluaran sistem sudah sesuai teori bahwa level yang lebih tinggi memiliki BER yang lebih besar. 


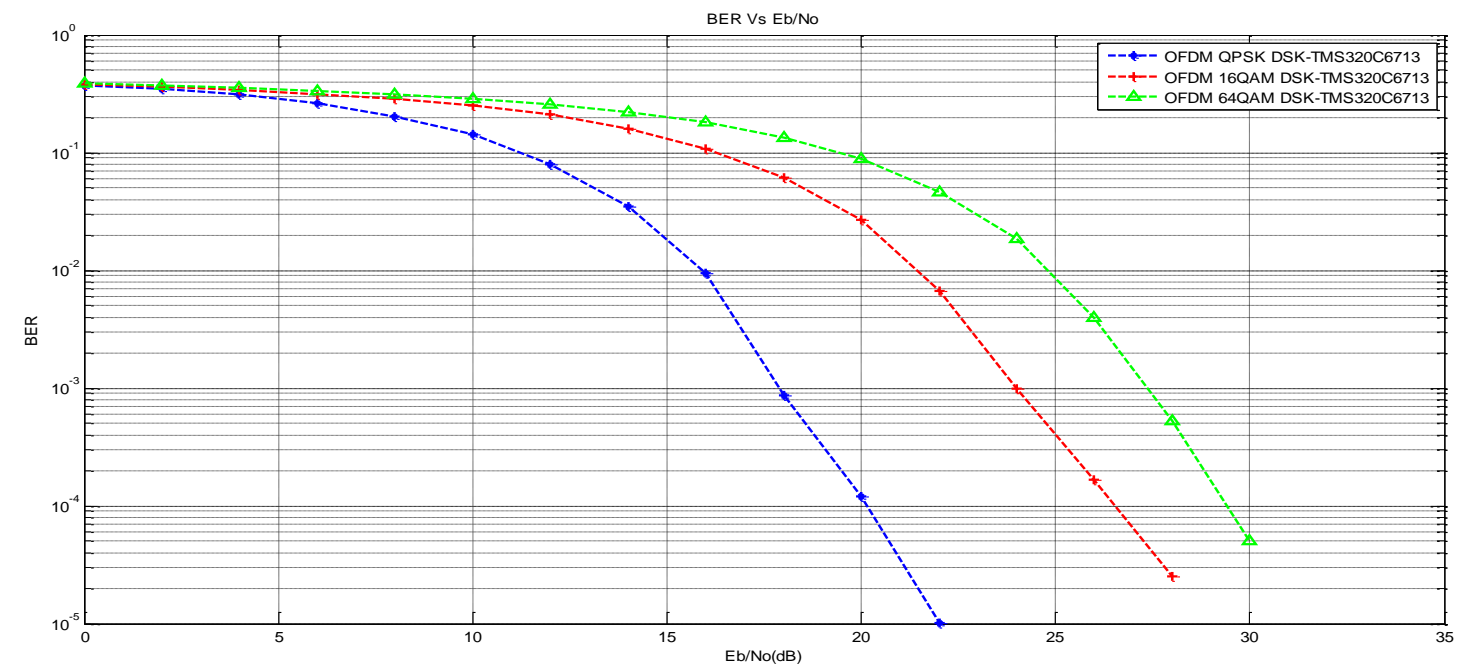

Gambar 9. BER sistem OFDM DSK TMS320C6713

\subsubsection{Analisis hasil BER sistem OFDM dengan Teori}

Sebelum melakukan analisis terhadap hasil BER dari pengujian sebelumnya, Gambar 10 merupakan hasil keluaran BER secara Teori, dengan pembatasan nilai BER pada angka $10^{-8}$ agar memudahkan dalam hal perbandingannya dengan keluaran dari $m$-file, simulink, dan DSKTMS320C6713.

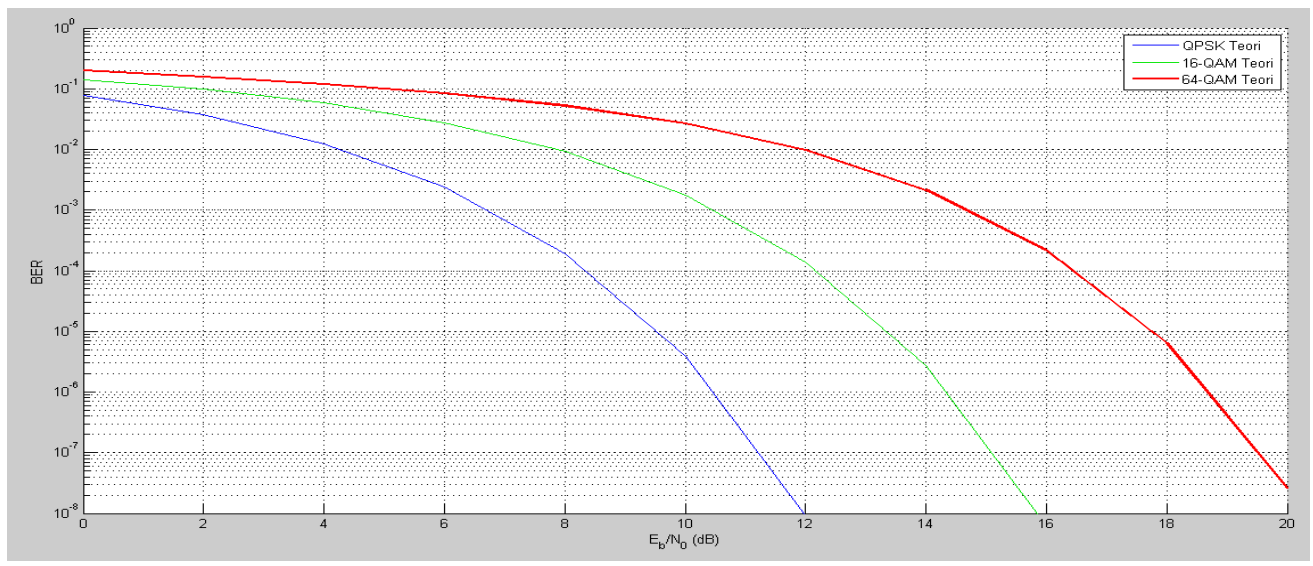

Gambar 10. Grafik BER secara Teori

Hasil BER secara teori lebih baik dari hasil BER yang keluar dari sistem, baik secara $m$ file, simulink, maupun DSK-TMS320C6713. Pada nilai Eb/No 8dB, hasil BER keluaran sistem pada DSK TMS320C6713 dengan modulasi QPSK yaitu 0,203700, dengan modulasi 16-QAM sebesar 0,286400, dan dengan modulasi 64-QAM sebesar 0,316200. Sedangkan BER secara Teori dengan Eb/No 8dB yaitu 0,0001909 untuk modulasi QPSK, 0,0092472 untuk modulasi 16-QAM, dan 0,0523338 untuk modulasi 64-QAM. Terdapat selisih sebesar 0,203509, 0,306953, 0,234066 masing masing untuk modulasi QPSK, 16AM, dan 64QAM. Hal Itu dikarenakan pada sistem secara teori, BER yang dihasilkan tidak menggunakan sistem OFDM, hasil BER teori hanya menggunakan satu buah subcarrier, sedangkan perancangan sistem menggunakan 192 subcarrier. Untuk itu BER yang dihasilkan secara teori bukan menjadi patokan nilai multak, tetapi yang menjadi patokannya adalah bahwa nilai BER dari modulasi QPSK selalu lebih baik dari 16QAM, kemudian nilai BER 16QAM lebih baik dari 64QAM 
Kemudian dari hasil keluaran sistem selalu terdapat perbedaan antara nilai BER yang dibuat pada m-file dengan simulink. Hal ini dimungkinkan terjadi dikarenakan pada model simulink, terdapat bagian blok blok yang perlu ditambahkan pada sistem agar model sistem nantinya dapat berjalan pada Kit DSK TMS320C6713. Blok blok ini yang kemungkinan penyebab dari bertambahnya jumlah data error yang dihasilkan oleh model simulink, dibandingkan dengan data yang yang dihasilkan oleh $m$-file. Adapun beberapa blok blok tersebut misalnya blok rate transitition, buffer, target preference, dll.

\subsubsection{Sistem dengan variasi jumlah data input}

Setelah dilakukan pengujian BER pada sistem dengan jumlah pengiriman data sebanyak 10.000 bit, kemudian dilakukan pengujian BER dengan jumlah data sebanyak 100.000 bit. Ini dilakukan untuk melihat apakah variasi jumlah data berpengaruh pada sistem atau tidak.

Dari hasil yang didapat, jumlah data yang dikirim sedikit memengaruhi kinerja sistem. Kadang kala dengan modulasi yang sama misalnya QPSK dengan nilai Eb/No yang sama, nilai BER pada pengiriman data 10.000 bit akan berbeda dengan pada saat pengiriman data 100.000 bit begitupun sebaliknya. Kemudian dilakukan rata rata dari hasil selisih tersebut untuk melihat modulasi manakah yang paling stabil terhadap pemberian variasi data yang dilakukan. Dan hasilnya dapat ditunjukan pada Tabel 2.

Tabel 2. Rata-rata selisih nilai BER antara 100.000 bit dan 10.000 bit

\begin{tabular}{|c|c|c|c|c|c|c|c|c|}
\hline \multicolumn{3}{|c|}{ 16QAM } & \multicolumn{3}{c|}{ 64QAM } & \multicolumn{3}{c|}{ QPSK } \\
\hline m-file & Simulink & DSK & m-file & Simulink & DSK & m-file & Simulink & DSK \\
\hline 0,001138481 & 0,001354317 & 0,001222488 & 0,001606 & 0,004308349 & 0,001434304 & 0,0020004 & 0,001771545 & 0,003363984 \\
\hline
\end{tabular}

Terlihat bahwa kinerja sistem dengan modulasi 16QAM memiliki nilai rata rata yang paling kecil dari ketiga jenis modulasi, yang dapat diartikan bahwa modulasi 16QAM adalah modulasi yang paling stabil terhadap variasi data yang dilakukan pada sistem ini.

\subsubsection{Pengamatan Kapasitas Penyimpanan Sistem pada DSK TMS320C6713}

Perangkat DSK TMS320C6713 memiliki kapasitas penyimpanan data sebesar 264 kbytes, Untuk itu total memory yang sudah di-transfer pada DSK menjadi salah satu bagian penting dalam tahapan implementasi pada perangkat tersebut. Pengamatan kapasitas penyimpanan dilakukan dengan cara mengambil data nilai memory dari setiap sistem yang telah diimplementasikan. Kemudian dilakukan perhitungan pada persamaan 6 untuk pengambilan nilai perbandingan memory yang terpakai terhadap kapasitas memory total dari DSK (y) dalam satuan persen (\%).

$$
y=\frac{\text { memory yang terpakai }}{\text { memory total DSK }} \cdot 100 \%
$$

Tabel 3. Memory yang terpakai pada DSK untuk setiap modulasi

\begin{tabular}{|c|c|c|}
\hline Modulasi & Memori (bytes) & $\mathrm{y}(\%)$ \\
\hline QPSK & 2780 & 1,0530303 \\
\hline 16-QAM & 2804 & 1,0621212 \\
\hline 64-QAM & 2804 & 1,0621212 \\
\hline
\end{tabular}

Hasilnya dari ketiga modulasi yang diimplementasikan, sistem yang paling efisien adalah sistem komunikasi dengan menggunakan modulasi QPSK dengan nilai 1,0530303\%. Sedangkan sistem dengam modulasi 16-QAM dan 64-QAM memiliki nilai efisiensi yang sama sebesar $1,0621212 \%$. 


\section{KESIMPULAN}

Dari hasil pengujian dan analisis yang dilakukan, didapat beberapa kesimpulan yang berhubungan dengan performansi sistem OFDM yang dibuat :

1. Simbol OFDM yang dihasilkan memiliki Perioda Total simbol Ttotal $=0,01 \mathrm{~s}$, dimana perioda simbol $\mathrm{Ts}=0,006 \mathrm{~s}$ dan $\mathrm{Tcp}=0,004 \mathrm{~s}$ baik secara simulasi ataupun DSK.

2. Perhitungan data rate yang paling besar yang bekerja pada sistem adalah data rate dengan modulasi 64QAM dengan nilai 115,2 Kb/s, sedangkan modulasi 16QAM yaitu sebesar 76,8 $\mathrm{Kb} / \mathrm{s}$ dan QPSK $38,4 \mathrm{~Kb} / \mathrm{s}$.

3. Hasil bit error rate (BER) yang ditunjukan pada saat implementasi, Modulasi QPSK memiliki nilai BER yang paling baik dari pada modulasi 16QAM dan 64QAM. Pada nilai Eb/No 10dB, modulasi QPSK memiliki nilai BER sebesar 0,14400, modulasi 16-QAM memiliki nilai BER sebesar 0,253600, dan modulasi 64-QAM memiliki nilai BER sebesar 0,288700 .

4. Sistem OFDM yang dibuat memiliki tingkat kestabilan yang paling baik dengan beberapa variasi data yang dikirim pada modulasi 16QAM, dengan nilai rata rata selisih BER pada hasil simulasi m-file sebesar 0,0011388481, simulink sebesar 0,001354317 dan DSK sebesar 0,001222488 .

5. Sistem OFDM dengan modulasi QPSK memiliki efisiensi yang paling baik sebesar $1,0530303 \%$ setelah diimplementasikan pada DSK TMS320C6713.

6. Sistem OFDM dengan beberapa modulasi ini telah berhasil diimplementasikan pada kit DSK-TMS320C6713 dengan baik

\section{Daftar Pustaka:}

[1] Aryanta, Dwi. 2014. Bahan kuliah sistem komunikasi 2. Bandung : Institut Teknologi Nasional

[2] Bodhe Rohit,et al. (2012). Design of simulink model for OFDM and Comparison of FFTOFDM and DWT-OFDM. Proceeding, International Journal of Engineering Science and Technology (IJEST)

[3] Djafar, Novan Ferdian. (2009). Rancang bangun rangkaian pengirim ODFM dengan Huffman code pada DSK-TMS320C6713 menggunakan simulink. Depok : Universitas Indonesia.

[4] Islam Shariful, Mahmud Asek Raihan, Hossain Alamgir, Ali Sadek. (2010). Performance Analysis of OFDM for Different Digital Modulation Schemes using Matlab Simulation. J. Bangladesh Electron. 10 (7-2); 7-11, 2010

[5] Purnomo, Heri. (2004). Sistem Komunikasi 2. Pekanbaru : politeknik caltex riau.

[6] Schulze, Henrik and Luders Christian. (2005). Theory and Application of OFDM and CDMA. England : John Wiley \& Sons Inc.

[7] Situmorang, Pontas P. (2009). Rancang bangun rangkaian penerima OFDM dengan menggunakan DSK-TMS320C6713 berbasis simulink. Depok : Universitas Indonesia.

[8] Wahyudi, Rundu Adi. (2008). Rancang bangun modulator 16-QAM pada DSKTMS320C6713 dengan menggunakan simulink. Depok : Universitas Indonesia.

[9] Haykin, Simon. 1989. Analog And Digital Communication. Canada : John Wiley \& Sons Inc. 